\title{
The Maturity of Tourism Networks: An Exploratory Study
}

\author{
Francesca d'Angella*, Manuela De Carlo**
}

\begin{abstract}
Networks in tourism are a growing phenomenon worldwide and tourism literature has devoted considerable space to networks' policies, governance forms, competitive advantages and activities. Literature that focuses on networks' operations generally analyzes what kind of activities are put in place without examining how they are carried out and whether they generate a competitive advantage. To fill this gap, our paper provides a notion of network maturity and introduces a taxonomy of the maturity levels of a network's operations.

The three-stage maturity model contributes to tourism literature by exploring how networks can evolve from basic to more sophisticated operations. From a managerial perspective, the paper contributes to evaluating network effectiveness and defining paths to improve it.
\end{abstract}

Keywords: Tourism Networks; Maturity Model; Network Maturity; Network Advantage; Global Tourism

\section{Tourism Networks}

Networks in tourism are a growing international phenomenon. In Italy business networks, particularly those bringing together firms from different industries, are a privileged way to overcome the limitations arising from the fragmentation of tourism players, the systemic nature of the tourism product, functional complementarities, territorial interdependencies, share of common local resources. Overcoming these limits is particularly urgent because the tourism system is currently characterized by intense evolutionary dynamics induced by the spread of ICT and its effects on the demand and the supply of tourist services; the development of managerial skills in the field; the vocational tourism which requires more customization of the product; the skilled and demanding customers.

Tourism management literature has dedicated ample space to business networks, exploring: the organizational structure; network policies and governance; the competitive advantage generated by the network; network operations (MerineroRodríguez \& Pulido-Fernandez, 2016; Volgger \& Pechlaner, 2015). The literature focused on networks' operations shows the existence of primary (promotion,

\footnotetext{
* Adjunct Professor of Marketing, University of Milan Bicocca (francesca.dangella@ unimib.it)

** Full Professor of Management, IULM University (manuela.decarlo@iulm.it)
} 
product development, booking and sales) and support (selection, coordination, planning, control) activities, but doesn't analyze them in terms of sophistication and effectiveness. This study aims to address this issue through an exploratory analysis that higlights the existence of different level of maturity and effectiveness of a network's activities (De Bruin et al., 2005; Kazanjian and Drazin, 1989).

\section{Literature Review}

The discussion on what networks are is still open (Rullani, 2010) as there is no univocal definition in literature (Grandori \& Soda, 1995; Nohria \& Eccles, 1992). However, the common denominator among the numerous definitions is the idea that a network is a set of nodes - organizations - linked by a set of relations (Fombun, 1982). The network concept has been developed by organizational studies focusing on inter-organizational relations (Aldrich and Whetten, 1981; Barabasi-Lazlo, 2002; Granovetter, 1983; Gulati, 1998; Knoke \& Yang, 2008; Levin \& White, 1961; Newman et al. 2006; Van de Ven, 1976). These studies provided theories on the antecedents and mechanisms behind network formation and on the economic and non-economic benefits springing from their implementation (Grandori \& Soda, 1995).

Studies based on social network analysis explored the morphological and structural features of networks through the study of the density and centrality of relational links.

Studies based on a managerial approach instead centered on the competitive and cooperative strategies enacted between the actors, the network's roles and institutionalization, power relations and the variations of these variables over time (Atkinson \& Coleman, 1992; Howlett \& Ramesh, 1998).

The "network" concept used in this study is in line with the managerial approach and it may be defined as a form of organization of the economic activities between companies. It coincides with the "cluster" concept proposed by Porter (1998): "Clusters are geographic concentrations of interconnected companies and institutions in a particular field. Clusters encompass an array of linked industries and other entities important to competition".

\subsection{Networking Advantages}

Numerous managerial studies analyzed inter-company aggregations as a source of competitive advantage for their members (Jarillo, 1988; Porter, 1998; Ritter et al., 2004). According to Porter (1998), through networking each member enjoys the same benefits it would have if it was larger in size or if it had established formal, permanent links with other businesses, but without losing its flexibility. Networks may affect the competiveness of their members in various ways: by increasing their productivity (Tresca, 2013), by improving their access to supply and labour markets and to specialized information, or by enhancing their operating processes (Vurro, et al. 2014). Moreover, the complementary services provided by the members increase the richness of each product. Lastly, networks enhance innovation and stimulate new businesses (Asheim \& Isaksen, 2003; Brondoni, 2015, 2010; Rullani, 2010; 
Wang \& Scuotto, 2012). An additional benefit of networks is the relational dimension that increases participating firms' social capital (Dyer \& Singh, 1998; Koka \& Prescott, 2002; Morieux, Blaxill \& Boutenko, 2005).

The issue of the advantages generated by business networks has also been explored by tourism studies (van der Zee \& Vanneste, 2015), which confirm the three advantages described above. In addition, there is a fourth benefit, related to specific aspects of the tourism industry: the creation of a link between the product or service sold by the company and the destination.

\section{Table 1: Network Advantages for Members}

\begin{tabular}{|c|c|}
\hline Advantages for network members & Reference studies \\
\hline $\begin{array}{l}\text { 1. Economic advantages (lower costs or greater value for customer) } \\
\text { - Expansion/higher quality of supply } \\
\text { - } \text { Product personalization in line with the needs of target segments } \\
\text { - Increase of sales } \\
\text { - } \text { Brand visibility } \\
\text { - Inclusion in new markets (and sharing of connected risks) }\end{array}$ & $\begin{array}{l}\text { Mitchell and van der Linden, } \\
\text { 2010; Braun, 2005; Morrison, } \\
\text { Lynch, Johns, 2004; Porter, } \\
\text { 2003,1998. }\end{array}$ \\
\hline $\begin{array}{l}\text { 2. Process advantages } \\
\text { - Greater access to information } \\
\text { - Greater efficiency in production processes (purchases, product } \\
\text { development, marketing and sales) given by the optimization of costs } \\
\text { (scale and volume economies, synergies due to sharing of technical, } \\
\text { human and financial resourcs) } \\
\text { - Innovation }\end{array}$ & $\begin{array}{l}\text { Paget, Dimanche and Mounet, } \\
\text { 2010; Ricciardi, 2010; Novelli, } \\
\text { Schmitz and Spencer, 2006; } \\
\text { Bell, 2005; Asheim and } \\
\text { Isaksen, 2003; Porter, 2003, } \\
1998 .\end{array}$ \\
\hline $\begin{array}{l}\text { 3. Relational advantages } \\
\begin{aligned} & \text { - } \text { Trust between operators } \\
& \text { - } \text { Knowledge \& capability sharing } \\
& \text { - } \text { Efficiency of organizational resources } \\
& \text { - } \text { Value sharing } \\
& \text { - } \text { Increased contacts with new customers and institutions (important } \\
& \text { network stakeholders) }\end{aligned}\end{array}$ & $\begin{array}{l}\text { Volgger \& Pechlaner, 2014; } \\
\text { Fait, 2012; Breukel \& Go, } \\
\text { 2009; Saxena, 2005; Morrison, } \\
\text { Lynch, Johns, } 2004 .\end{array}$ \\
\hline $\begin{array}{l}\text { 4. B rand advantages / land identity } \\
\text { - customer's perception of the specificity of tourism products deriving } \\
\text { from the link with the destination (product-destination relation) } \\
-\quad \text { customer royalty creation }\end{array}$ & Hall, 2005 \\
\hline
\end{tabular}

\subsection{Networks Operations}

Within the management literature on networks, a considerable number of papers focuses on networks' operations. As for companies, the networks' activities may be split into (Porter, 1985): primary activities, related to product development, and support activities, focused on managing the network's operations to enhance its effectiveness.

Primary activities include the development of integrated products, the promotion of both services provided by network members and integrated products, reservations and sales (Denicolai, et al. 2010; Mitchell \& van der Linden, 2010; Novelli et al. 2006). The implementation of one or more of these activities is 
generally the motivation which leads to the institution of the network (Zehrer \& Raich, 2010), and they are a source of competitive advantage for network's members.

The support activities include members' selection, control and support and coordination of the network. Those activities regulate the network's functioning and they guarantee network stability (Lemmetyinen \& Go, 2009; Pesamaa et al. 2007; Romiti \& Sarti, 2013; Zehrer \& Raich, 2010).

Table 2: Tourism Network Activities

\begin{tabular}{|l|l|}
\hline $\begin{array}{l}\text { Activities undertaken by } \\
\text { tourism networks }\end{array}$ & Reference studies \\
\hline 1. Promotion & $\begin{array}{l}\text { Lemmetyinen \& Go, 2010; Cawleya, Marsatb \& Gillmor, 2007; } \\
\text { Pforr, 2006; Braun, 2003; Telfer, 2001 }\end{array}$ \\
\hline 2. Product development & $\begin{array}{l}\text { Sfandla \& Bjork, 2013; Novelli, Schmitz \& Spencer, 2006; Mitchell } \\
\text { \& van der Linden, 2010; Petroua, Pantziou, Dimara \& Skuras, } \\
\text { 2007; Pavlovich, 2003 }\end{array}$ \\
\hline 3. Booking and sale & Pencarelli, 2003; Braun, 2002 \\
\hline 4. Coordination & $\begin{array}{l}\text { Beaumont \& Dredge, 2010; Lemmetyinen \& Go, 2009; Zucchella, } \\
\text { 2007; Dredge, 2006 }\end{array}$ \\
\hline $\begin{array}{l}\text { 5. Selection, control and } \\
\text { support }\end{array}$ & $\begin{array}{l}\text { Pesamaa, Ortqvist \& Hair, 2007; Huang, 2006; Ingram \& Roberts, } \\
\text { 2000 }\end{array}$ \\
\hline
\end{tabular}

The majoriy of tourism contributions identify networks activities without examining "how" they are carried out, which is, however, an important factor in achieving a sustainable competitive advantage (Porter, 1985). This paper therefore aims to identify the ways in which tourism networks carry out their primary and support activities, highlighting various levels of sophistication through the empirical research described in the following sections.

\section{Methodology}

The methodology is based on an analysis of academic studies focusing on networking and a desk analysis of a sample of national and international business networks.

The international literature analysis on tourism networks aims to define the network concept, to identify the activities carried out by business networks and to pinpoint the main advantages that network strategies may offer to tourism companies. The analysis considers all the articles published in the two most prestigious international tourism reviews: Annals of Tourism Research and Tourism Management. These studies have been integrated by a keyword analysis of the articles published in other leading tourism journals, carried out on EBSCO, Google Scholar, and Science Direct data banks. The analysis covers the decade 2004-2014. Several articles published previously, comprising a reference for 
theoretical studies on networks or presenting an empirical analysis of special interest $\mathrm{t}^{\mathrm{i}}$, were also considered.

The empirical analysis is based on a mix method that combine quantitative and qualitative research (Brewer \& Hunter, 2006; Tashakkori \& Teddlie, 1998). It was carried out from January to April 2014 on a sample of 100 tourism business networks set up in the top 20 regional destinations for tourist overnights, plus the Italian Regions not included in that list (Veneto, Tuscany, Lazio and Lombardy had already appeared/been listed in the top 20 world tourism regions).

Network identification is based on a desk analysis of the official tourism websites managed by the regional destination management organization (hereafter DMO). If the regional website showed no networks, we checked on the Province portals, plus a desk study through keywords. The table below shows the sample composition and a descriptive of the quantitative results.

Table 3: Descriptive Analysis (frequencies)

\begin{tabular}{|l|l|}
\hline Participants & $\begin{array}{l}47 \% \text { homogeneous networks - composed of a single category of } \\
\text { subjects (e.g. hotels), 53\% heterogeneous networks }\end{array}$ \\
\hline Composition & $54 \%$ only private organizations, 46\% private and public actors \\
\hline Nationality & $60 \%$ Italian, $40 \%$ European \\
\hline \multirow{4}{*}{ Activities } & promotion $100 \%$ \\
\cline { 2 - 2 } & product development $82 \%$ \\
\cline { 2 - 2 } & booking and sales 32\% \\
\cline { 2 - 2 } & coordination $100 \%$ \\
\cline { 2 - 2 } & selection, control and support $100 \%$ \\
\hline
\end{tabular}

The sample includes a balanced mix of homogeneous (47\%) and heterogeneous networks $(53 \%)$. Even regarding the nature of the bodies involved, the sample includes a balanced mix of aggregations of private organizations (54\% of sample) and aggregations of private and public actors (46\%). Looking at the activities carried out by the network, support activities are present in the $100 \%$ of the sample, while primary activities show different frequencies. Promotion is a key activity, always present in tourism networks and in some cases it is the reason why they have been set up. Product development is quite present (82\%), while booking and sales is carried out only by the $32 \%$ of the sample.

\section{Qualitative Results}

The different ways networks carry out primary and support activities has suggested the existence of three levels of maturity corresponding to growing levels of ability (elementary, intermediate, evolved) in carrying out operations. 
Table 4: The Network's Matury Model

\begin{tabular}{|c|c|c|c|}
\hline \multirow[b]{2}{*}{ Primary activities } & \multicolumn{3}{|c|}{ Sophistication in network's operations } \\
\hline & Basic level & Intermediate level & Advanced level \\
\hline Reservation & $\begin{array}{l}\text { - Just a list of members' contacts } \\
\text { (eg. link to their websites) }\end{array}$ & $\begin{array}{l}\text { - Reservation without the } \\
\text { possibility of buying online (eg, } \\
\text { quotations and redirection of } \\
\text { requests) }\end{array}$ & $\begin{array}{l}\text { - Direct sales through own tools } \\
\text { or provided by third parties (eg } \\
\text { reservation systems embedded in } \\
\text { the site) } \\
\text { - Sales through intermediaries } \\
\text { (TO, AdV, OLTA) }\end{array}$ \\
\hline $\begin{array}{l}\text { Product } \\
\text { development }\end{array}$ & $\begin{array}{l}\text { Offer of basic touris m products } \\
\text { and services without any form of } \\
\text { integration }\end{array}$ & $\begin{array}{l}\text { - Presence of services directed at } \\
\text { specific targets and / or thematic } \\
\text { offers } \\
\text { - Possibility to design customized } \\
\text { products }\end{array}$ & $\begin{array}{l}\text { - Proposal of experiential tourism } \\
\text { offers } \\
\text { - Integration of not tourist } \\
\text { industries (eg, agriculture, trade, } \\
\text { handicrafts and other } \\
\text { manufacturing activities) }\end{array}$ \\
\hline Promotion & $\begin{array}{l}\text { List of the services offered by } \\
\text { the network members }\end{array}$ & $\begin{array}{l}\text { Promotion of integrated tourism } \\
\text { products through tools and } \\
\text { dedicated channels (website, } \\
\text { brochures, etc.). }\end{array}$ & $\begin{array}{l}\text { - Promotion of integrated tourism } \\
\text { products through dedicated tools } \\
\text { (website, brochures, etc.). } \\
\text { - Development and promotion of } \\
\text { the network brand } \\
\text { - Presence of a communication/ } \\
\text { marketing plan marketing }\end{array}$ \\
\hline \multicolumn{4}{|l|}{ Support activities } \\
\hline Coordination & $\begin{array}{l}\text { - Informal coordination } \\
\text { mechanisms } \\
\text { - Communication mainly } \\
\text { unidirectional, from management / } \\
\text { coordinator to members of the } \\
\text { network }\end{array}$ & $\begin{array}{l}\text { - Formal coordination mechanisms } \\
\text { (regular meetings) } \\
\text { - Formal coordination structures } \\
\text { (eg board of directors and } \\
\text { shareholders, etc.). }\end{array}$ & $\begin{array}{l}\text { - Formal coordination } \\
\text { mechanisms (regular meetings) } \\
\text { - Structured planning activities } \\
\text { - Dedicated full time managers } \\
\text { with specialization of roles } \\
\text { - Institutional Communication to } \\
\text { the territory (eg local communities, } \\
\text { associations, public institutions) }\end{array}$ \\
\hline $\begin{array}{l}\text { Selection, control \& } \\
\text { support to members }\end{array}$ & $\begin{array}{l}\text { - Aggregation operators on the } \\
\text { basis of a feature / theme } \\
\text { - Generic requirements for } \\
\text { membership } \\
\text { - No disciplinary } \\
\text { - Self-certification }\end{array}$ & $\begin{array}{l}\text { - Certification of the presence of } \\
\text { specific services or requirements } \\
\text { (eg, quality brand, disciplinary) } \\
\text { - Verification of the compliance } \\
\text { with requirements only when } \\
\text { entering the network }\end{array}$ & $\begin{array}{l}\text { - Regular Monitoring of } \\
\text { compliance with the } \\
\text { - Support for the companies: } \\
\text { - Training } \\
\text { - Coaching } \\
\text { - Dynamic disciplinary } \\
\text { (Progressive increase of the } \\
\text { services' level of quality) } \\
\text { - In heterogeneous networks, } \\
\text { presence of a specific disciplinary } \\
\text { for each category of subjects }\end{array}$ \\
\hline
\end{tabular}

Advanced reservation activities are based on third-party platforms (eg. reservation system embedded in the site), own platforms or through intermediaries (tour operators, travel agents, OTA). Although they can generate distribution costs, these platforms afford individual companies "process advantages" due to greater efficiency and "economic advantages" due to increased visibility and accessibility to the products, which results in higher market coverage and sales.

The product development activities, if operated on an advanced level, enable companies to enjoy the benefits of "relational advantages" due to more contacts with customers and partners in the destination; "process advantages" related to a joint product development; and "economic advantages" attributable to higher value for the customer. Indeed, they allow the network to create products characterized by a significant concept expressed in a brand/logo/theme that communicates a 
unitary and consistent fruition experience, and which adds value to its components (services and attractions). Moreover, evolved product development activities generate coordinated price systems (e.g. cards) and customers' dynamic involvement in the choice of the product components according to their needs and preferences.

Finally, advanced promotion activities generate for network members both "process and economic advantages" due to promotion cost optimization and a greater brand visibility. Besides, they generate "advantages of brand/ land identity" as they increases the customers' perception of the unique features of the product, also in relation to the territory.

As for the support activities, if carried out with high levels of sophistication, they guarantee an efficient and effective network operations in the long term, which is a necessary condition for the development of the primary activities described above.

\section{Conclusions}

This study contributes to the academic literature proposing a taxonomy of the maturity levels of a network's operations, which corresponds to different levels of sophistication in performing network activities. Regarding managerial implications, the paper helps evaluate existing networks and define pathways to improving the effectiveness of the network in the long term. As networks put in place by DMOs are quite diffused worldwide, the findings of this study could be of interest not only for networkmanagers, but also for destination managers in charge of network development.

The empirical study has some limitations related to the empirical research methodology, which relies only on secondary data, potentially incomplete but able to retrieve the behaviours actually existing. Moreover, to ensure greater objectivity in the results, each network was analyzed independently by two researchers.

This exploratory study should be strengthened by further research based on larger samples. The hypothesis is that advanced business networks offer greater advantages to their members compared to basic networks. The evidence presented in this paper represents only a first step in a process of ongoing research, which will focus on the measurement of the network effectiveness.

\section{Bibliography}

Atkinson, M., \& Coleman, W. (1992). Policy Networks, Policy Communities and the Problems of Governance. Governance, 5(2), 154-180.

http://dx.doi.org/10.1111/j.1468-0491.1992.tb00034.x

Aldrich, H., \& Whetten, H. (1981). Organization-sets, action-sets and networks: making the mos out of simplicity, in Nystrom, P., \& Starbuck, W. (eds), Handbook of Organizational Design (pp. 385-408). New York: Oxford University Press.

Asheim, B. T., \& Isaksen, A. (2003). SMEs and the regional dimension of innovation, in Asheim, B., Isaksen, A., Nauwelaers, C., \& Tödtling, F. (Eds.), Regional innovation policy for smallmedium enterprises (pp. 21-46). Edward Elgar, Cheltenham: UK.

Barabási-Lazlo, A (2002). Linked: The New Science of Networks. Cambridge: Perseus Publishing. 
Beaumont, N. \& Dredge, D. (2010). Local tourism governance: a comparison of three network approaches. Journal of Sustainable Tourism, 18(1), 7-28.

http://dx.doi.org/10.1080/09669580903215139

Bell, G. (2005). Clusters, networks, and firm innovativeness. Strategic Management Journal, 26, 287-295.

http://dx.doi.org/10.1002/smj.448

Braun, P. (2005). Creating value to tourism products through tourism networks and clusters: uncovering destination value chains. Article presented at $O E C D \&$ Korea Conference on Global Tourism Growth: A Challenge for SMEs.

Braun, P. (2003). Regional tourism networks: the nexus between ICT diffusion and change in Australia. Information Technology \& Tourism, 6, 1-13.

http://dx.doi.org/10.3727/1098305032781139

Braun, P. (2002). Networking tourism SMEs: E-Commerce and E-marketing issues in regional Australia. Information Technology \& Tourism, 5(1), 13-24.

Breukel, A., \& Go, F. (2009). Knowledge-based network participation in destination and event marketing: A hospitality scenario analysis perspective. Tourism Management, 30, 184-193. http://dx.doi.org/10.1016/j.tourman.2008.05.015

Brewer, J., \& Hunter, A. (2006). Foundations of multimethod research: Synthesizing styles (2nd ed.). Thousand Oaks, CA: Sage.

Brondoni, S. (2015). Global Networks, Outside-In Capabilities and Smart Innovation. Symphonya Emerging Issues in Management (symphonya.unimib.it), 1, 6-21.

http://dx.doi.org/10.4468/2015.1.02brondoni

Brondoni S. (2010). Intangibles, Global Networks \& Corporate Social Responsibility. Symphonya. Emerging Issues in Management (symphonya.unimib.it), 2, 6-24.

http://dx.doi.org/10.4468/2010.2.02brondoni

Cawleya, M., Marsatb, J.B., \& Gillmor, D. (2007). Promoting Integrated Rural Tourism: Comparative Perspectives on Institutional Networking in France and Ireland. Tourism Geographies: An International Journal of Tourism Space, Place and Environment, 9(4), 405-420. http://dx.doi.org/10.1080/14616680701647626

De Bruin, T., Freeze, R., Kaulkarni, U., \& Rosemann, M. (2005). Understanding the Main Phases of Developing a Maturity Assessment Model. Paper presented at the Australasian Conference on Information Systems (ACIS), Australia, New South Wales, Sydney. Retrieved from http://eprints.qut.edu.au/25152/

Denicolai, S., Cioccarelli, G., \& Zucchella, A. (2010). Resource-based local development and networked core-competencies for tourism excellence. Tourism Management, 31(2), 272-278.

http://dx.doi.org/10.1016/j.tourman.2009.03.002

Dredge, D. (2006). Policy networks and the local organisation of tourism. Tourism Management, 27, 269-280.

http://dx.doi.org/10.1016/j.tourman.2004.10.003

Dyer, J. H., \& Singh, H. (1998). The relational view: Cooperative strategy and sources of interorganizational competitive advantage. Academy of management review, 23(4), 660-679.

http://dx.doi.org/10.5465/AMR.1998.1255632

Fombrun, C. (1982). Strategies for Network Research in Organizations. The Academy of Management Review, 7(2), 280-291.

http://dx.doi.org/10.5465/AMR.1982.4285594

Grandori, A., \& Soda, G. (1995). Inter-firm Networks: Antecedents, Mechanisms and Forms. Organization Studies, 16(2), 183-214.

http://dx.doi.org/10.1177/017084069501600201 
Granovetter, M. (1983). The Strength of Weak Ties: a Network Theory Revisited. Sociological Theory, 1, 201-233.

http://dx.doi.org/10.2307/202051

Gulati, R. 1998. Alliances and networks. Strategic Management Journal, 19 (4), 293-317.

Hall, C. (2005). Rural wine and food tourism cluster and network development, in Hall, Kirkpatrick \& Mitchell, Rural tourism and sustainable business. UK: Channels View Publications

Howlett, M., \& Ramesh, M. (1998). Policy Subsystem Configurations and Policy Change: Operationalizing the Postpositivist Analysis of the Politics of the Policy Process. Policy Studies Journal, 26(3), 466-481. http://dx.doi.org/10.1111/j.1541-0072.1998.tb01913.x

Huang, L. (2006). Building up a B2B e-commerce strategic alliance model under an uncertain environment for Taiwan's travel agencies. Tourism Management, 27(6), 1308-1320. http://dx.doi.org/10.1016/j.tourman.2005.06.005

Ingram, P., \& Roberts, P. (2000). Friendships among Competitors in the Sydney Hotel Industry, American Journal of Sociology, 106(2), 387-423. http://dx.doi.org/10.1086/316965

Jarillo, J. C. (1988). On strategic networks. Strategic Management Journal, 9(1), 31-41. http://dx.doi.org/10.1002/smj.4250090104

Kazanjian, R.K., \& Drazin, R. (1989). An empirical test of stage of growth progression model. Management Science, 35(12), 1489-1503. http://dx.doi.org/10.1287/mnsc.35.12.1489

Knoke, D., \& Yang, S. (2008). Social Network Analysis. Sage: Los Angeles.

Koka, B., Prescott, J. (2002). Strategic alliances as social capital: A multidimensional view. Strategic Management Journal, 23(9), 795-816.

http://dx.doi.org/10.1002/smj.252

Lemmetyinen, A., \& Go, F. (2010). Building a brand identity in a network of Cruise Baltic's destinations: A multi-authoring approach. Journal of Brand Management, 17, 519-531.

http://dx.doi.org/10.1057/bm.2010.5

Lemmetyinen, A., \& Go, F. (2009). The key capabilities required for managing tourism business networks. Tourism Management, 30, 31-40.

http://dx.doi.org/10.1108/17579881211248781

Merinero-Rodríguez, R., \& Pulido-Fernandez, J. (2016). Analysing relationships in tourism: A review. Tourism Management, 54(6), 122-135.

http://dx.doi.org/10.1016/j.tourman.2015.10.010

Mitchell, R., \& van der Linden, J. (2010). Adding value through cooperation: A study of the New Zealand food and wine tourism network, paper presented at 5th International Academy of Wine Business Research Conference, 8-10 Feb. Auckland.

Morieux, Y., Blaxill, M., \& Boutenko, V. (2005). Restructuring strategies. New networks and industry challenges, In Cool K., Henderson J., \& Abate R. (eds.) Restructuring Strategies (pp. 86-109). New York: Blackwell Publishing.

Morrison, A., Lynch, P., \& Johns, N. (2004). International tourism networks. International Journal of Contemporary Hospitality Management, 16(3), 197-202.

http://dx.doi.org/10.1108/09596110410531195

Newman M .E.J., Barabasi A.L., \& Watts D J. (2006). The Structure and Dynamics of Networks. Princeton: University Press.

Nohria, N., \& Eccles, R. (eds) (1992). Networks and Organizations: Structure, Form, and Action. Boston: Harvard Business School Press.

Novelli, M., Schmitz, B., \& Spenser, T. (2006). Networks, clusters and innovation in tourism: A UK experience. Tourism Management, 27(6), 1141-1152. 
http://dx.doi.org/10.1016/j.tourman.2005.11.011

Paget, E., Dimanche, F., \& Mounet, JP. (2010). A tourism innovation case. An Actor-Network Approach. Annals of Tourism Research, 37(3), 828-847.

http://dx.doi.org/10.1016/j.annals.2010.02.004

Pavlovich, K. (2003). The evolution and transformation of a tourism destination network: the Waitomo Caves, New Zealand. Tourism Management, 24(2), 203-216.

http://dx.doi.org/10.1016/S0261-5177(02)00056-0

Pesamaa, O., Ortqvist, D., \& Hair, J. (2007). It's all about Trust and Loyalty: Partner Selection Mechanisms in Tourism Networks. Munich Personal RePEc Archive, MPRA Paper 8428.

Petrou, A., Fiallo Pantzioua, E., Dimaraa, E. \& Skuras D. (2007). Resources and Activities Complementarities: the Role of Business Networks in the Provision of Integrated Rural Tourism. Tourism Geographies: An International Journal of Tourism Space, Place and Environment, 9(4), 421-440.

http://dx.doi.org/10.1080/14616680701647634

Pforr, C. (2006). Tourism policy in the making. An Australian Network Study. Annals of Tourism Research, 33(1), 87-108.

http://dx.doi.org/10.1016/j.annals.2005.04.004

Porter, M. (2003). Clusters and Regional Competitiveness: Recent Learnings. Paper presentato a International Conference on Technology Clusters, Montreal, Canada.

Porter, M. (1998). Clusters and the New Economics of Competition. Harvard Business Review, (November-December), 77-90.

Porter, M. (1985). Competitive Advantage: Creating and Sustaining Superior Performance. USA: Simon \& Schuster.

Ritter, T., Wilkinson, I., \& Johnston, W. (2004). Managing in complex business networks. Industrial Marketing Management, 33(3), 175-183.

http://dx.doi.org/10.1016/j.indmarman.2003.10.016

Romiti, A., \& Sarti, D. (2013). Le fasi iniziali dell'evoluzione delle reti di impresa. Alcuni casi nel settore della meccanica. Impresa Progetto. Electronic Journal of Management, (1), 1-33.

Rullani E. (2010). Network economy: evolution of small firm capitalism and on the "made in Italy" sector. Economia e Politica industriale, 4, 141-165.

http://dx.doi.org/10.3280/poli2010-004007

Saxena, G. (2005). Relationships, networks and the learning regions: case evidence from the Peak District National Park. Tourism Management, 26, 277-289.

http://dx.doi.org/10.1016/j.tourman.2003.11.013

Sfandla, C., \& Bjork, P. (2013). Tourism Experience Network: Co-creation of Experiences in Interactive Processes. International Journal of Tourism Research, 15(5), 495-506.

http://dx.doi.org/10.1002/jtr.1892

Tashakkori, A., \& Teddlie, C. (1998). Mixed methodology: Combining qualitative and quantitative approaches. Thousand Oaks, CA: Sage.

Telfer, D. (2001). Strategic alliances along the Niagara Wine Route. Tourism Management, 22(1), $21-30$.

http://dx.doi.org/10.1016/S0261-5177(00)00033-9

Tresca, R. (2013). Global Business Networks and Competitiveness of SMEs. Symphonya Emerging Issues in Management (symphonya.unimib.it), 2, 67-78.

http://dx.doi.org/10.4468/2013.2.05tresca

Van de Ven, A. (1976). On the Nature, Formation, and Maintenance of Relations among Organizations. Academy of Management Review, 1(4), 24-36.

http://dx.doi.org/10.5465/AMR.1976.4396447 
van der Zee, E., \& Vanneste, D. (2015). Tourism networks unravelled; a review of the literature on networks in tourism management studies. Tourism Management Perspectives, 15(7), 46-56. http://dx.doi.org/10.1016/j.tmp.2015.03.006

Volgger, M., \& Pechlaner, H. (2015). Governing networks in tourism: what have we achieved, what is still to be done and learned? Tourism Review, 70(4), 298-312. http://dx.doi.org/10.1108/TR-04-2015-0013

Vurro, C., Russo, A., \& Costanzo, L. (2014). Sustainability along the Value Chain: Collaborative Approaches and their Impact on Firm Performance. Symphonya Emerging Issues in Management (symphonya.unimib.it), 2, 30-44.

http://dx.doi.org/10.4468/2014.2.04vurro.russo.costanzo

Wang, D., \& Scuotto, V. (2012). Innovation, Second Mover and Network System. Symphonya Emerging Issues in Management (symphonya.unimib.it), 2, 66-76. http://dx.doi.org/10.4468/2012.2.06wang.scuotto

Zehrer, A., \& Raich, F. (2010). Applying a lifecycle perspective to explain tourism network development. The Service Industries Journal, 30(10), 1683-1705.

http://dx.doi.org/10.1080/02642060903580698

Zucchella, A. (2007). Network Social Responsibility. Symphonya. Emerging Issues in Management (symphonya.unimib.it), 2, 69-77.

http://dx.doi.org/10.4468/2007.2.07zucchella 
Attachment 1: The Tourism Networks included in the Sample

\begin{tabular}{|c|c|c|}
\hline Region & $\begin{array}{c}\text { N. } \\
\text { networks }\end{array}$ & Network name \\
\hline Abruzzo & 1 & Provincia del benessere \\
\hline Alto Adige & 6 & $\begin{array}{l}\text { Vitalpina Hotels, Gallo Rosso - Osterie contadine, Bikehotels Südtirol, Belvita Leading Wellnesshotels, } \\
\text { Familienhotels Südtirol, Südtirol privat - affittacamere } \\
\end{array}$ \\
\hline Basilicata & 8 & $\begin{array}{l}\text { Bike Hotel Basilicata, Walking Hotel Basilicata, Sapori di Basilicata, Mountain bike hotel Basilicata, } \\
\text { Vacanza attiva Basilicata, Family hotel Basilicata, Os pitalità Glamour, B\&B Qualità }\end{array}$ \\
\hline Emilia Romagna & 4 & Unioni di prodotto: Città d'Arte, Costa Adriatica, Appennino e Verde, Terme \\
\hline Friuli Venezia Giulia & 6 & $\begin{array}{l}\text { L'Italia della Grande Guerra, Terre di Aquileia by Bike, Family Hotels \& Campings, Dimore di charme, Terra } \\
\text { dei Patriarchi, Albergo diffuso }\end{array}$ \\
\hline Lazio & 1 & Strada del vino cesanese \\
\hline Liguria & 2 & Club Hiking, Club Biking \\
\hline Lombardy & 1 & Strada del vino/sapori della Valtellina \\
\hline Piedmont & 3 & Club Sapori Torinesi, Bed\&Bike, Residenze Reali di Torino e del Piemonte \\
\hline Sardinia & 1 & Domos Historicas \\
\hline Tuscany & 1 & Strada del Chianti Classico \\
\hline Trentino & 10 & $\begin{array}{l}\text { Osterie Tipiche Trentine, Dolomiti Walking Hotels, Vitanova wellness, Giocovacanza family hotels, Cuore } \\
\text { rurale, Trentino Charme, Trentino in moto, B\&B di qualità, Club Appartamenti, Qualità parco adamello- } \\
\text { brenta }\end{array}$ \\
\hline Umbria & 6 & $\begin{array}{l}\text { Umbria Experience, Strade del vino e dell'olio, Umbria Benessere, Umbria Bike Hotel, Umbriamore, Umbria } \\
\text { Convention Bureau }\end{array}$ \\
\hline Valle d'Aosta & 6 & $\begin{array}{l}\text { Saveurs du Val d'Aoste, Bike Valle d'Aosta, Wellness Valle d'Aosta, Slow holiday, Viva Vda, Route des } \\
\text { Vins }\end{array}$ \\
\hline Veneto & 4 & $\begin{array}{l}\text { Associazione Ville Venete, Treviso provincia dello sport, Strada del vino dei colli euganei, Club AgriCycle } \\
\text { Veneto }\end{array}$ \\
\hline \multicolumn{3}{|c|}{ International networks } \\
\hline Andalusia (E) & 7 & $\begin{array}{l}\text { Caminos de Cultura, Naturaleza y paisajes, Caminos de los Sentidos, Caminos de la Tradición, Caminos de } \\
\text { Emoción, Caminos de lo Auténtico, Andalusian Wilderness }\end{array}$ \\
\hline Aquitaine $(\mathrm{F})$ & 1 & DestinationVignobles \\
\hline Balearic Islands (E) & 3 & Club de Producto Náutico, Club de productro gastronomico Menorca, Mallorca Golf Island \\
\hline Canary Islands (E) & 4 & Volcanic Experience, Water Sports Experience, Wellness Delight, Family Welcome \\
\hline Catalunya (E) & 8 & \begin{tabular}{|l} 
Destinació de Turisme Esportiu, Cultura Calatunya, Turisme Gastronòmic, Actiu-Natura, Turisme de Golf, \\
Programma Turisme Accessible, Programma Turisme Rural, Destinació de Turisme Familiar \\
\end{tabular} \\
\hline $\begin{array}{l}\text { Valensian } \\
\text { Communities (E) }\end{array}$ & 2 & Club de Producto Turis mo Náutico, Club de Producto Turismo de Salud y Calidad de Vida \\
\hline Lingua d'Oc $(\mathrm{F})$ & 2 & Cercle Prestige, Club Business \\
\hline $\begin{array}{l}\text { Mecklenburg- } \\
\text { Vorpommern (D) } \\
\end{array}$ & 1 & Familienurlaub MV-Geprüfte Qualität \\
\hline $\begin{array}{l}\text { Oberbayern / } \\
\text { Baviera (D) }\end{array}$ & 3 & $\begin{array}{l}\text { Fahrradfreundlichen Hotel- und Gaststättenbetriebe, Alpen-Kulinarik Gasthöfe, Motorradfreundlicher } \\
\text { Hotel- und Gastronomiebetrieb }\end{array}$ \\
\hline $\begin{array}{l}\text { Provence Alps Cote } \\
\text { d'Azur (F) }\end{array}$ & 3 & Golf Tourism PACA, Destination Prestige Provence, Bistrot de Pays \\
\hline Tyrol (A) & 6 & $\begin{array}{l}5 \text { tirolergletscher, Climbers Paradise Tirol, Nature watch tirol, Wander Hotels, Familienhotels Tirol, } \\
\text { Vacanze in fattoria }\end{array}$ \\
\hline
\end{tabular}

\section{Notes}

i Tourism journals: Annals of Tourism Research, International Journal of Contemporary Hospitality Management, Journal of Destination Marketing and Management, Journal of Sustainable Tourism, Journal of Travel \& Tourism Marketing, The Service Industries Journal, Tourism Management, World Journal of Tourism Small Business Management.

International management journals: Harvard Business Review, Journal of Public Administration Research and Theory, Organization Science, Strategic Management Journal.

Italian journals: Amministrazione e finanza, Impresa progetto, Sinergie. 